\title{
State Governance Tools for Environmental Management and Agrarian Business in the Digital Age
}

\author{
HANNA OBYKHOD ${ }^{1}$, YOSYP DOROSH ${ }^{2}$, TETIANA KHARCHENKO ${ }^{3}$, NADIYA STOVOLOS ${ }^{4}$, \\ YEVHENII LEVKIVSKYI ${ }^{5}$, TETIANA SAMOILENKO ${ }^{3}$ \\ ${ }^{1}$ Natural-Technogenic and Environmental Safety Department, PUBLIC INSTITUTION INSTITUTE OF \\ ENVIRONMENTAL ECONOMICS AND SUSTAINABLE DEVELOPMENT OF THE NATIONAL ACADEMY OF SCIENCES \\ OF UKRAINE, UKRAINE. E-mail: hanna.oby@gmail.com \\ ${ }^{2}$ INSTITUTE OF LAND MANAGEMENT OF NATIONAL ACADEMY OF AGRARIAN SCIENCES OF UKRAINE, UKRAINE \\ ${ }^{3}$ Public Management and Administration Department, SUMY NATIONAL AGRARIAN UNIVERSITY, UKRAINE \\ ${ }^{4}$ Economy Department, SUMY NATIONAL AGRARIAN UNIVERSITY, UKRAINE \\ ${ }^{5}$ International Economic Relations and European Integration Department, ZHYTOMYR NATIONAL
} AGROECOLOGICAL UNIVERSITY, UKRAINE

\begin{abstract}
Because of the acceleration of the development of various types of business in the era of global digitalization, the authors propose to pay attention to the regulation of environmental management and agricultural business, as well as to offer tools for state regulation of this aspect. To do this, the authors analyzed the impact of the digital era on various aspects, studied foreign experience in reducing the negative environmental impact of digital technologies. The authors analyzed the current state of the domestic agricultural business and gave forecasts for its development. All this allowed the authors to develop tools for state management of environmental management and agricultural business in the digital era, namely, the main tools and ways to reduce the negative impact of the agricultural business on environmental management using ICT, as well as the main steps of the state program for the rational use of natural resources in the region.
\end{abstract}

Keywords: Agrarian Business, Digital Age, Environmental Management, State Governance Tools.

JEL Classification: G18, Q14, M21 


\section{Introduction.}

The main features of the information-digital economy are its global nature and the operation of intangible goods: ideas, information and relationships, network principles in the coordination of markets and society. In the digital economy, the world of subtle technologies controls machines; the virtual world changes the behaviour of the real (Galkin et al., 2019; Tkachenko et al., 2019; Shpak et al., 2020). It is these features that create new types of markets and societies (Boiko et al., 2019). The technological foundation of the digital economy is created based on the discoveries of the fourth industrial revolution. Among them are artificial intelligence, distributed data, the Internet of things and for things, blockchain, mining centres, big data and cloud storage, digital platforms, 3D and then 4D printing (Basiurkina et al., 2020).

The digital economy growing based on the information economy can be defined as its continuation in a new quality after a technological breakthrough as a result of the fourth industrial revolution, which is characterized by a nonlinear (exponential) rate of innovation spread, the depth and scale of penetration of digital technologies, the power of influence of digital complexes and systems. Their use changes a lot in the way of thinking and motivating decisions, i.e. not only in productivity but also in economic behaviour, in the principles of organization and operation of companies and the entire economic mechanism (Dzwigol \& Dzwigol-Barosz, 2020).

Digital technologies play a critical role in achieving a long-term balance between the technosphere and the natural environment, which is essential for sustainable development (Shpak et al., 2019).

In an innovative economy, business is continually changing under the influence of the political, legal, economic, technological and cultural environment, which becomes a prerequisite for the emergence or transformation of forms of entrepreneurship (Halkiv et al., 2020). At the current level of internationalization of the economy, the integration of economic agents already goes beyond the traditional forms of international business, namely foreign trade, foreign investment, licensing and joint ventures (Mura \& Gašparíková, 2010). New are considered to be international networking, engineering, outsourcing, crowdsourcing, crowdfunding, etc., which use in their activities not only multinational companies as significant players in the global economy but also small firms and companies. Such changes make it possible to introduce the latest forms of entrepreneurship in rural areas (Trusova et al., 2019). In the context of European integration processes, decentralization of management and finding ways to diversify the agricultural economy, identifying mechanisms for the development of new forms of international business in rural areas of Ukraine becomes especially important. Global economic integration for the agrarian sector is manifested in increasing the openness of agri-food markets by ensuring the free movement of agricultural products, works and services. Accordingly, European integration has created additional opportunities for the development of agribusiness as a fundamental sector of rural areas and the use of experience in the effectiveness of rural development tools, but on the other hand, exacerbated their problems, as the competitiveness of agribusiness is relatively low compared to European products (Tekin, 2013; Czyżewski et al., 2019). Rural areas face the need to diversify their economy, which is based on the relocation of available resources to new types of agricultural and non-agricultural activities and helps to create opportunities to improve living standards in rural areas. The implementation of the strategy of diversification in rural areas of Ukraine is slow, which is explained by the peculiarities of the rural mentality, the way of life of peasants, insufficient funding of local budgets, technological backwardness, etc. (Styskal et al., 2016; Shynkaruk et al., 2020).

However, with the development of agribusiness, the negative impact on nature, resources, etc. increases (Mura \& Ključnikov, 2018), so the state needs to look for effective mechanisms to restore the balance between nature management and agribusiness in the digital age (Kvaterniuk et al., 2017; Mitryasova, 2017; Kwilinski et al., 2020; Prokopenko et al., 2020). 


\section{Agrarian business in Ukraine.}

One of the most critical problems of the domestic economy is the development of a mechanism for the revival of agribusiness. There are many reasons for the decline of the Ukrainian countryside. They lie in the economic, as well as institutional and psychological planes: on the one hand, the state has only formed the legal basis for rural development, agricultural business and has provided little implementation in financial and institutional aspects, on the other - fragile public position of the rural population, low level of self-organization and the psychological stereotype of thinking that the state itself will do everything for their well-being.

Table 1. Economic accounts of agriculture (production account and income account), in actual prices; million

\begin{tabular}{|c|c|c|c|c|c|c|}
\hline \multicolumn{7}{|c|}{ hryvnias } \\
\hline \begin{tabular}{|c|} 
EAA \\
code $^{1}$
\end{tabular} & Types/groups of products/activities & 2015 & 2016 & 2017 & 2018 & $2019^{2}$ \\
\hline 01 & Cereals & 163856 & 214155 & 226918 & 296578 & 288400 \\
\hline 02 & Technical crops & 131191 & 170627 & 173845 & 207752 & 189748 \\
\hline 03 & Fodder crops & 7268 & 8015 & 8562 & 9735 & 9087 \\
\hline 04 & Vegetable crops & 33917 & 31883 & 33446 & 35700 & 45428 \\
\hline 05 & Potato & 41095 & 41862 & 53515 & 53252 & 63698 \\
\hline 06 & Fruits, berries, grapes & 18390 & 18262 & 23741 & 23547 & 24769 \\
\hline 09 & Other crop products & 1902 & 2323 & 2608 & 2662 & 2821 \\
\hline 10 & Crop production $(01 \div 09)$ & 397619 & 487127 & 522635 & 629226 & 623951 \\
\hline 11 & Livestock (farm animals) & 69056 & 70527 & 87933 & 106005 & 108451 \\
\hline 12 & Livestock products & 65582 & 67931 & 84327 & 94930 & 92539 \\
\hline 13 & Livestock production $(11+12)$ & 134638 & 138458 & 172260 & 200935 & 200990 \\
\hline 14 & Production of agricultural products $(10+13)$ & 532257 & 625585 & 694895 & 830161 & 824941 \\
\hline 15 & Production of agricultural services & 8256 & 8455 & 8998 & 12764 & 13097 \\
\hline 16 & Production of agricultural products $(14+15)$ & 540513 & 634040 & 703893 & 842925 & 838038 \\
\hline 17 & Non-agricultural secondary activities (integral) & 3693 & 3751 & 3899 & 4662 & 4729 \\
\hline 18 & Agricultural output $(16+17)$ & 544206 & 637791 & 707792 & 847587 & 842767 \\
\hline 19 & Intermediate consumption & 311838 & 367396 & 414115 & 499916 & 498519 \\
\hline 20 & Gross value added (18-19) & 232368 & 270395 & 293677 & 347671 & 344248 \\
\hline 21 & Consumption of fixed capital & 14010 & 16315 & 23162 & 29369 & $\cdots$ \\
\hline 22 & Net value added (20-21) & 218358 & 254080 & 270515 & 318302 & $\ldots$ \\
\hline 23 & Remuneration of employees & 34038 & 39731 & 52810 & 71483 & $\ldots$ \\
\hline 24 & Other taxes on production & 3078 & 1934 & 2677 & 2862 & $\ldots$ \\
\hline 25 & Other subsidies on production & 1732 & 1676 & 5841 & 3051 & $\ldots$ \\
\hline 26 & Factor income $(22-24+25)$ & 217012 & 253822 & 273679 & 318491 & $\cdots$ \\
\hline 27 & Net current income/mixed-income $(22-24-23+25)$ & 182974 & 214091 & 220869 & 247008 & $\ldots$ \\
\hline
\end{tabular}

${ }_{1}^{1}$ Indicators by types/groups of products/activities are formed following the codes of economic accounts of agriculture (EAA). ${ }^{2}$ Preliminary data.

Source: Research findings

Over the last 10 years, there has been a growing trend in Factor Income and Net Current Income (Fig. 1). 
Figure 1. Dynamics and forecast of Factor income and net current income in the agrarian business, 2015-2019,

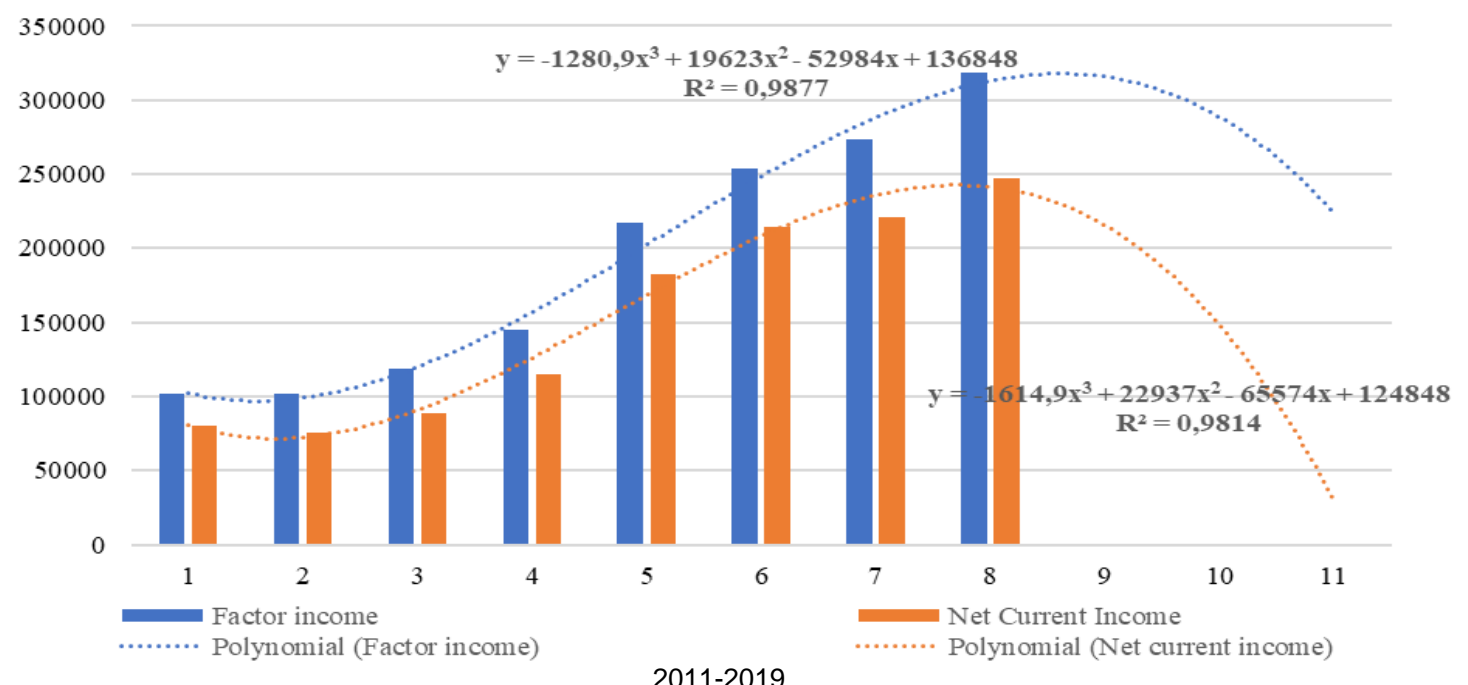

Source: Research findings

However, the forecast shows that a recession is expected with constant trends.

Studies of agricultural business development have shown the most acute problems (Fig. 2).

Figure 2. The most acute problems of agricultural business

\begin{tabular}{|l|l|l|l|}
\hline \multicolumn{3}{|c|}{ PROBLEMS OF AGRICULTURAL BUSINESS } \\
\begin{tabular}{|l|c|c|c|}
\hline lack of motivation to work & labour migration & decline of social structure \\
\hline deepening demographic crisis & low efficiency of agrarian business \\
\hline
\end{tabular} \\
\hline
\end{tabular}

Source: Research findings

Therefore, it is necessary to study the experience of agrarian business, in particular, rural areas in developed countries.

\section{Research of foreign experience.}

We believe that the most suitable and promising for Ukraine is the European model because it provides for the implementation of rural development policy, which is accompanied and supplemented by agricultural policy and policy to support the profitability of agricultural production. European policy has evolved as part of the development of the Common Agricultural Policy (CAP) from a policy addressing the structural problems of the agricultural sector to a policy focused on the multifunctionality of agribusiness and, in particular, the challenges facing rural development (Buckwell et al., 2019).

The first steps in shaping the policy of agricultural business development were measures to stimulate investment in agriculture and declining sectors. Support for processing and marketing is designed to integrate all components of the production chain from production to sale and contribute to the further improvement of agricultural structures and the competitiveness of the raw materials sector. The policy of stimulating the development of agriculture in the EU countries is aimed at ensuring high performance in agricultural production, socio-economic processes, the intensification of rural entrepreneurship (Tekin, 2013). The EU's common agricultural policy has significant benefits 
for European farmers. We are talking about the allocation of subsidies from the multibillion-dollar budget of the European Union to support producers. In cases of drought, floods and other natural phenomena, losses are reimbursed from the funds of agricultural insurance credit funds. To assist farms in case of financial difficulties in the EU, there are special funds: the European Fund for Social Development, the European Social Fund, the European Equalization and Guarantee Fund. Direct payments to farmers are accrued according to mandatory and selective schemes. The basic scheme provides for equal payments per 1 hectare, regardless of the crops grown or livestock. Among the methods that have a positive impact on the climate and the environment are the so-called "green payments", which account for $30 \%$ of the national distribution of funds. Special subsidies are also provided to young farmers up to 40 years of age who started agricultural activity not earlier than 5 years before applying for the support (Feng, 2007; Nelson et al., 2019; Diakoulakis et al., 2020). European rural development policy helps EU rural areas to address a wide range of economic, environmental and social issues. This is provided for in the main basic principles of the CAP of the European Union (Fig. 3).

Figure 3. The basic principles of the EU's Common Agrarian Policy

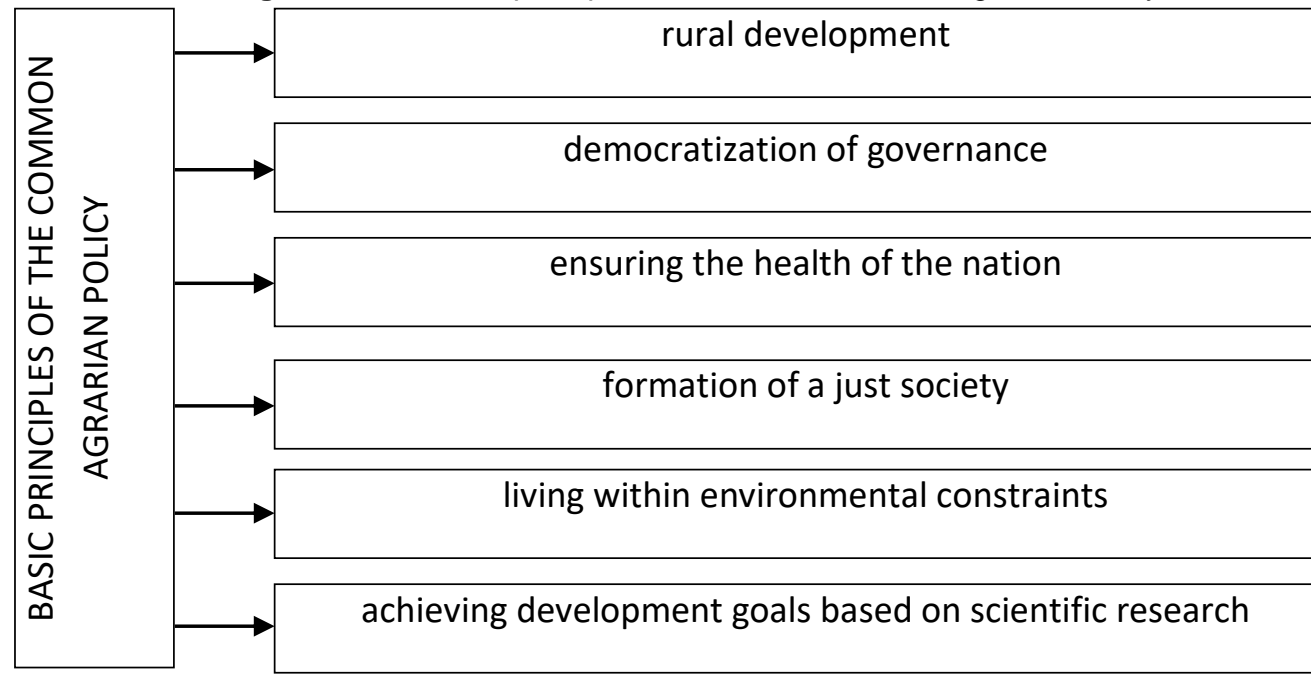

Source: Research findings

However, the development of agribusiness leads to environmental pollution, and therefore the state needs to look for tools to manage nature and agribusiness in the digital age.

\section{Results and discussion.}

The mechanism of state management of nature management involves a comprehensive combination and use of administrative and legal, economic, financial and credit, socio-political, moral and psychological and other tools and incentives. The mechanism of nature management and ecological safety is a holistic set of management methods and tools, by means of which nature management processes are organized, regulated and coordinated in combination with production and socio-economic processes, the proper level of ecological safety of production and consumption is provided public good.

The main tools of state regulation the environmental management of natural capital conservation are shown in Fig. 4. To reduce the negative impact of agrarian business on environmental management is necessary to introduce information and computer technologies (ICT) (Fig. 4).

The formation of environmental management should be based on the basic principle that ecological security of the state has become an essential element and component of national security. The provisions that develop this principle have been enshrined in the Constitution of Ukraine, several other laws and bylaws. The essence of state nature management is determined by the ecological policy of the state, which aims to preserve safe for living and inanimate environment, to protect life 
and health from the adverse effects of environmental pollution, to achieve harmonious interaction of society and nature, protection, rational use and reproduction of natural resources.

Figure 4. The main ways to reduce the negative impact of agricultural business on environmental management using ICT

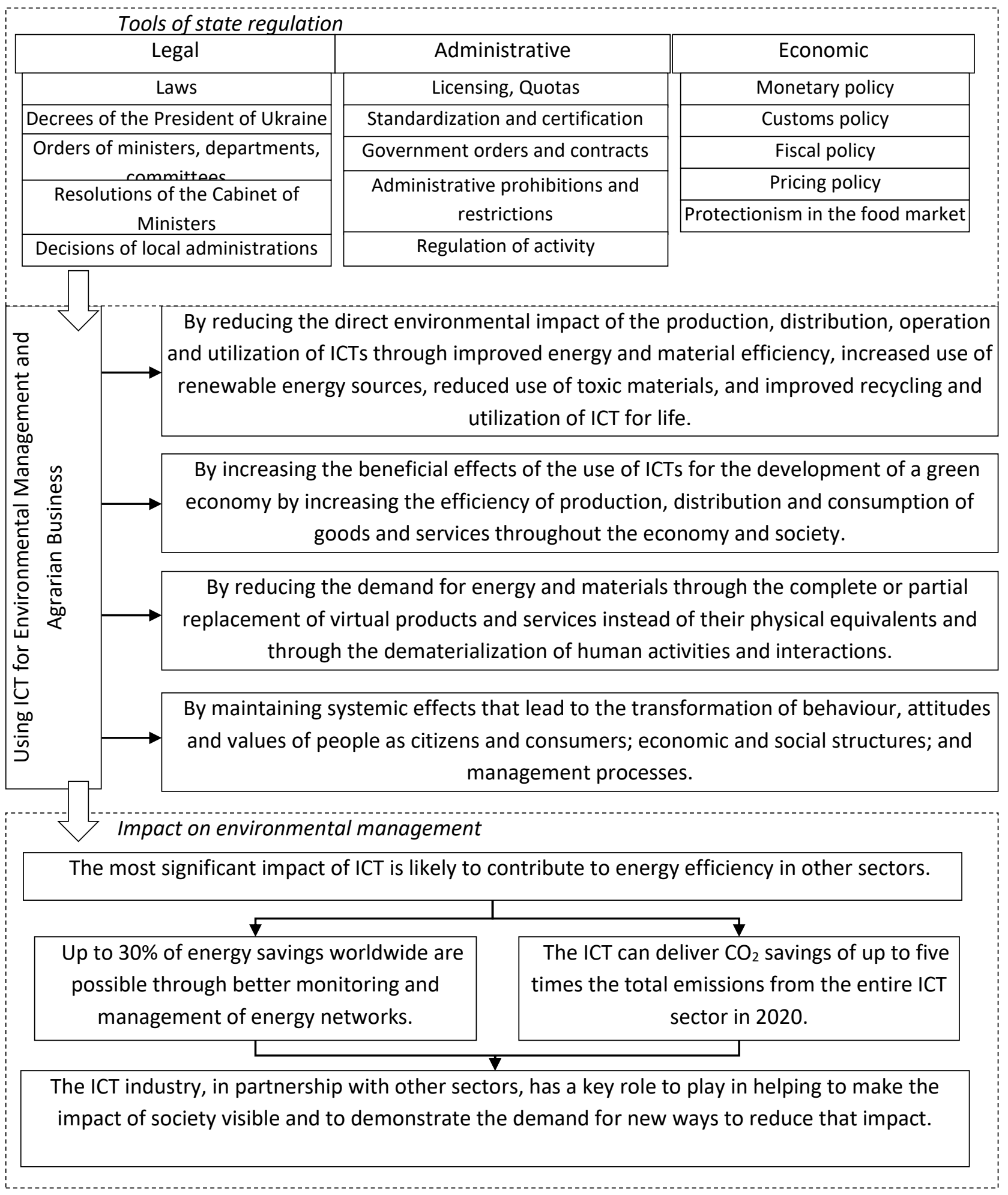

Source: Research findings

The agricultural business has significant prospects for development, especially with the involvement of foreign partners and/or their capital. This type of cooperation can cause the most significant damage to nature, because foreign partners are usually in their own country and, if they 
do not have a socially responsible consciousness, are not very confused about the state of the environment of other countries.

To prevent the negative impact of anthropogenic agribusiness on the environment, as well as the irrational use of natural resources in Ukraine, in addition to the above mechanism, the following environmental procedures should be applied: environmental expertise, environmental monitoring, ecological insurance and environmental audit. Environment.

Environmental expertise is one of the levers of government regulation. Environmental expertise covers sketches for the development and placement of productive forces, development of economic sectors, master plans of settlements, district planning schemes and other pre-design and pre-design documentation; feasibility studies and calculations of enterprises and other facilities, construction and reconstruction projects; drafts of educational and methodological and normative and technical acts and documents regulating economic activities; documents for the development of new equipment, technologies, materials and materials, including those purchased abroad; substances, materials, systems and facilities, the introduction and implementation of which may violate environmental safety standards and harm the environment.

Environmental monitoring includes the systematic collection, processing, transfer, storage and analysis of ecological information, forecasting its changes and the development of sound scientific recommendations for decision-making to prevent adverse environmental changes and comply with environmental safety requirements. Within the framework of ecological monitoring, the following activities are carried out: monitoring of the quality of air, water, soil; radiation monitoring; monitoring of biological resources, etc.

State control over compliance with the requirements of environmental legislation in the field of waste management, rational use of natural resources (except for subsoil and forests), the environment and its competence to combat radiation; compliance with the rules, norms, standards; compliance with permissive conditions, limits and quotas issued for particular uses of natural resources (except for subsoil and forests), emissions and discharges of pollutants into the environment and permissible levels of harmful effects of physical and biological factors on its condition, transboundary movement of plants and animals world; Compliance with environmental requirements and, within its competence for radiation protection, is carried out by the State Environmental (Ecological) Inspectorate.

One of the most important means of regulating state relations in the field of environmental protection and the agro-industrial complex is standardization and regulation, which should be mandatory and include:

- environmental safety standards (maximum permissible concentration of pollutants in the environment, maximum allowable levels of acoustic, electromagnetic, radiation and other harmful effects on the ground, maximum allowable levels of harmful substances in food);

- top permissible emission and discharge rates, levels of exposure to toxic physical and biological agents.

Environmental standards must be consistent with the requirements for protecting the environment and human health from the adverse effects of pollution. Today we can say that Ukraine has laid the foundations for the economic mechanism of environmental management.

Thus, the most critical tool for state management of relationships with nature and regulation of the agro-industrial complex in the digital era and solving environmental problems is the planning of a target program, the development and implementation of target ecological programs.

These programs must be adjusted for each area because they all have different potential for nature management and agricultural business. Accordingly, we propose the broadest target Program of environmental management (Fig. 5). 
Figure 5. State program for environmental management in the region

STATE PROGRAM FOR ENVIRONMENTAL MANAGEMENT IN THE REGION

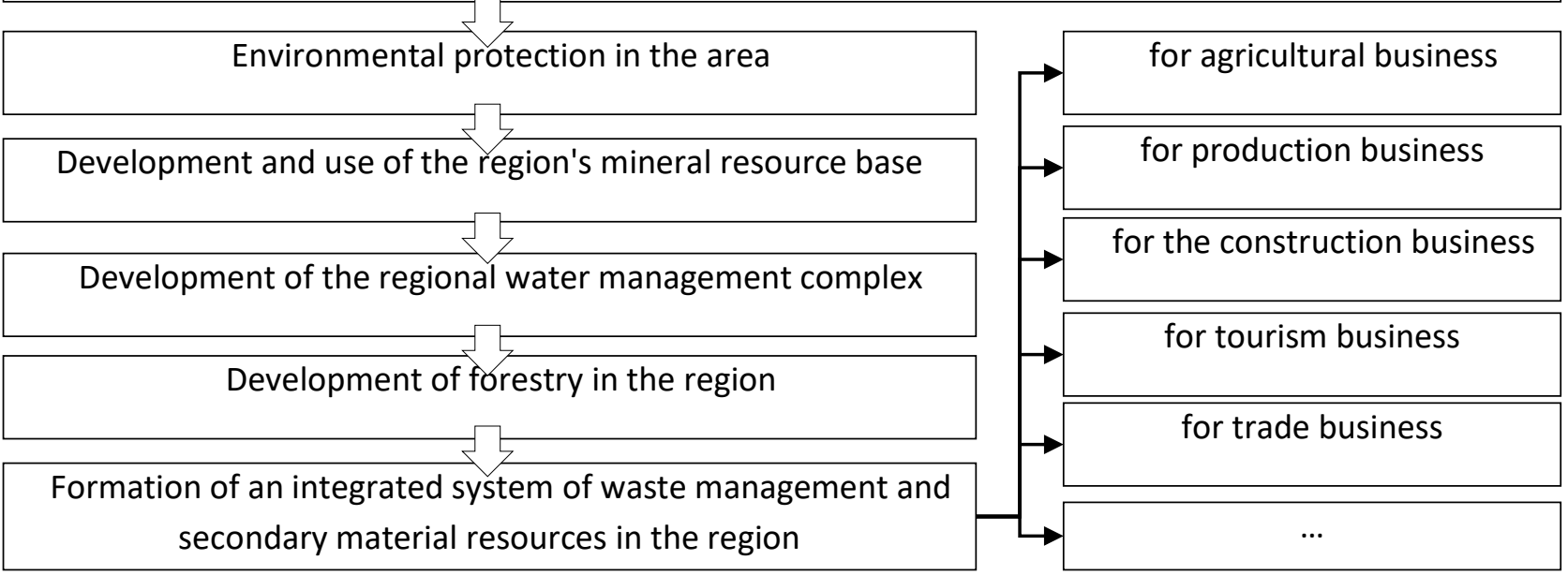

Source: Research findings

The Program is a document that defines the main directions, priority tasks of the state policy of the region to improve the state of the environment. Besides, strategic management of natural resources should be carried out within the framework of the state program for environmental protection and rational use of natural resources.

The program should describe a set of measures aimed at solving priority tasks in the field of environmental protection and ensuring rational use of natural resources in the region, the implementation of which will contribute to ensuring ecological safety, sustainable functioning of biological, ecological systems, preserving biodiversity, protecting the territories and population of the region from negative the impact of all types of business, including agro, the improvement of the ecological situation, the provision of raw materials needs of the economic complex and the creation of conditions for increasing the efficiency of using the resources of the region and/or increasing the forest cover of its territory (where possible and necessary).

The choice of the Program activities should be based on an analysis of the environmental situation in the area, which identified the most acute problems; therefore it cannot be absolutely applicable to all areas without adjustment.

\section{Conclusion.}

State regulation of relations in the field of nature management plays a vital role in solving many environmental problems, namely, the preservation of biological diversity, depletion or overuse of non-renewable natural resources, disruption of unique ecosystems, conservation of natural capital.

The natural capital conservation management system has a complex multidisciplinary structure. Thus, the creation of an effective management system for nature conservation is possible provided the best international experience of developed countries in combination with national characteristics, the formation of a single methodological framework of normative indicators with their legislative consolidation, attracting economic incentives for natural capital conservation (grants, awards, eco-grants, eco-grants, eco-grants), emissions trading, implementation of green economy instruments). The involvement of incentive tools for the preservation of natural capital will form an effective mechanism for state regulation of agrarian business development in the digital age and its impact. 


\section{References}

1. Basiurkina, N. et al. (2020). Substantiation of the innovation and investment project using the method of real options. International Journal of Management, 11 (5), 497-510.

2. Buckwell, A. et al. (2019). The Common Agricultural Policy. The Costs of the Common Agricultural Policy, DOI: 10.4324/9780429293160-2

3. Boiko, V. et al. (2019). Competitive Advantages of Wholesale Markets of Agricultural Products as a Type of Entrepreneurial Activity: The Experience of Ukraine and Poland. Economic Annals-XXI, 175(1-2), 68-72. https://doi.org/10.21003/ea.V175-12

4. Czyżewski, B. et al. (2019). Public goods versus the farm price-cost squeeze: shaping the sustainability of the EU's common agricultural policy. Technological and Economic Development of Economy, 25(1), 82-102. https://doi.org/10.3846/tede.2019.7449

5. Diakoulakis, G. et al. (2020). A goal-framing approach to green payments' efficiency when vertical integration is an option, DOI: 10.13140/RG.2.2.14399.94881

6. Dzwigol, H., \& Dzwigol-Barosz, M. (2020). Sustainable Development of the Company on the Basis of Expert Assessment of the Investment Strategy. Academy of Strategic Management Journal, 19(5), 1-7.

7. Feng, H. (2007). Green payments and dual policy goals. Journal of Environmental Economics and Management, 54(3), 323-335. DOI: 10.1016/j.jeem.2007.03.003

8. Halkiv, L. et al. (2020). Modeling and forecasting of innovative, scientific and technical activity indicators under unstable economic situation in the country: Case of Ukraine. Communications in Computer and Information Science, 1158, 79-97.

9. Khytrova, O. et al. (2020). Ensuring the Growth of Enterprises and Organizations through the Motivation of Managerial Staff. International Journal of Economics and Business Administration, VIII (2), 219-228.

10.Kuzior, A. et al. (2019). Sustainable Development of Organizations Based on the Combinatorial Model of Artificial Intelligence. Entrepreneurship and Sustainability, 7(2), 1353-1376. DOI: 10.9770/jesi.2019.7.2(39)

11.Galkin, A. et al. (2019). Interaction of logistics 4.0 and Consumer Oriented Marketing Using ICT. Proceedings of the 33rd International Business Information Management Association Conference, IBIMA 2019: Education Excellence and Innovation Management through Vision 2020, 33, 67516760.

12.Kvaterniuk, S. et al. (2018). Mathematical modeling of light scattering in natural water environments with phytoplankton particles. International Multidisciplinary Scientific GeoConference Surveying Geology and Mining Ecology Management, SGEM, 18 (2.1), 545-552.

13. Kwilinski, A. et al. (2020). Information Support of the Entrepreneurship Model Complex with the Application of Cloud Technologies. Journal of Entrepreneurship Education, 23(SI1), 1-9. https://www.abacademies.org/articles/Information-support-of-the-entrepreneurship-1528-265123-S1-557.pdf

14. Mitryasova, O. et al. (2017). Integrated environmental assessment of the surface waters pollution: regional aspect. 17th International Multidisciplinary Scientific Geoconference, SGEM 2017, Vienna, 17(33), 235-242.

15.Mura, L., \& Ključnikov, A. (2018). Small businesses in rural tourism and agro tourism: Study from Slovakia. Economics and Sociology, 11(3), 286-300.

16.Mura, L., \& Gašparíková, V. (2010). Penetration of small and medium sized food companies on foreign markets. Acta Universitatis Agriculturae et Silviculturae Mendelianae Brunensis, 58(3), 157-163. 
17.Nelson E. et al. (2019). The distributional impact of a green payment policy for organic fruit. PLoS ONE, 14(2), e0211199, DOI: 10.1371/journal.pone.0211199

18.Prokopenko, O. et al. (2020). Adaptation of the development of ecological entrepreneurship. International Journal of Scientific and Technology Research, 9(3), 1112-1115.

19.Shpak, N. et al. (2019). Validation of ecologists in enterprise management system: a case study analysis. Polish Journal of Management Studies, 19(1), 376-390. DOI: 10.17512/pjms.2019.19.1.29

20.Shpak, N. et al. (2020). Digitalization of the Marketing Activities of Enterprises: Case Study. Information, 11, 109. DOI: 10.3390/info11020109

21.Shynkaruk, L. et al. (2020). Modelling of land relations in Ukraine in the period of institutional transformations. International Journal of Management, 11(4), 622-633.

22.Styskal, O. et al. (2016). Assessment of chlorinated water impact on phytoplankton. 16th International Multidisciplinary Scientific Geoconference, SGEM2016, Vienna, AUSTRIA, 373-380.

23.Tekin, N. (2011). Common agricultural policy. Law \& justice, IV(1), 183-199.

24.Tkachenko, V. et al. (2019). Assessment of Information Technologies Influence on Financial Security of Economy. Journal of Security and Sustainability, 8(3), 375-385. DOI: 10.9770/jssi.2019.8.3(7)

25.Trusova, N. et al. (2019). Determinants of the development venture financing of the subjects of Agrarian market of Ukraine. Asia Life Sciences, (1), 377-398. 